\title{
Nonpathogenic Fusarium oxysporum Strain Fo47 Induces Resistance to Fusarium Wilt in Tomato
}

J.-G. Fuchs, Y. Moënne-Loccoz, and G. Défago, Institute for Plant Sciences/Phytopathology, Swiss Federal Institute of Technology (ETH Zentrum), Universitätstr. 2, CH-8092 Zürich, Switzerland

\begin{abstract}
Fuchs, J.-G., Moënne-Loccoz, Y., and Défago, G. 1997. Nonpathogenic Fusarium oxysporum strain Fo47 induces resistance to Fusarium wilt in tomato. Plant Dis. 81:492-496.

Nonpathogenic Fusarium oxysporum strain Fo47 controls the incidence of Fusarium wilt. Four bioassays in which a strain of the pathogen F. oxysporum f. sp. lycopersici and Fo47 were not in direct contact were developed to evaluate whether Fo47 could induce resistance to Fusarium wilt in tomato plants. Fo47 and the pathogen were separated either physically or in time. Bioassays were carried out under hydroponic conditions (two bioassays), in potting mix, or in autoclaved soil. Strain Fo47 protected tomato against Fusarium wilt in all four bioassays. Inoculation with Fo47 increased chitinase, $\beta$-1,3-glucanase, and $\beta$-1,4-glucosidase activity in plants, confirming the ability of Fo47 to induce resistance in tomato. This report is the first to demonstrate that a nonpathogenic strain of $F$. oxysporum can induce resistance to Fusarium wilt in tomato plants. This result has important practical implications for biocontrol of tomato diseases under commercial conditions.
\end{abstract}

Fusarium oxysporum Schlechtend. f. sp. lycopersici W.C. Snyder \& H.N. Hans. causes Fusarium wilt in tomato and is responsible for important crop losses in fields and commercial greenhouses (5). Nonpathogenic $F$. oxysporum strain Fo47 was isolated from a soil suppressive to Fusarium wilt at Châteaurenard, France, and its efficacy at reducing the severity of Fusarium wilt has been demonstrated several times $(1,4,8,21,23)$. Earlier work with the strain indicated that competition for infection sites on the root surface and for nutrients (e.g., carbon and iron) were important factors involved in the protection achieved by Fo47 against Fusarium wilt $(1-3,22)$.

Work carried out with other fungi has indicated that certain strains could also protect plants through induction of resistance (20). Induced resistance can be local, often associated with a hypersensitive response, or systemic, when an entire plant becomes protected against later inoculations with a pathogen (28). Systemic induced resistance can be detected by implementing challengeinoculation at a later time and different location on a plant (39). In the case of Fusarium wilts, Mandeel and Baker (26) have shown that nonpathogenic strains of $F$. oxysporum can induce resistance to Fusarium

Corresponding author: G. Défago

E-mail: defago@path.ipw.ethz.ch

Current address of J.-G. Fuchs: Biophyt AG, Schulstr. 13, CH-5465 Mellikon, Switzerland.

Accepted for publication 27 January 1997.

Publication no. D-1997-0326-05R

(C) 1997 The American Phytopathological Society wilt in cucumber. Likewise, nonpathogenic isolates of $F$. oxysporum can induce resistance to Fusarium wilt in chickpea (14). In the case of tomato plants, induced resistance to Fusarium wilt has been achieved with formae speciales of $F$. oxysporum pathogenic to carnation (19). Whether nonpathogenic strains of $F$. $o x$ ysporum are able to induce resistance to Fusarium wilt in tomato has not been clearly demonstrated.

The objective of the current investigation was to determine whether nonpathogenic strain $F$. oxysporum Fo47 can induce resistance to Fusarium wilt in tomato plants. Four different bioassays in which a pathogenic strain causing Fusarium wilt and nonpathogenic strain Fo47 were not in direct contact were developed and tested. In addition, strain Fo47 was studied for its ability to induce physiological changes in tomato plants, as indicated by modifications in the activity of certain plant glycosidases.

\section{MATERIALS AND METHODS}

Organisms and culture conditions. Nonpathogenic $F$. oxysporum strain Fo47 was isolated by Alabouvette et al. (4) from a suppressive soil at Châteaurenard. F. oxysporum f. sp. lycopersici strain Fol8 race $\mathrm{O}$ (8) causes Fusarium wilt of tomato (Lycopersicon esculentum Mill.), and Fol8B is a spontaneous mutant of Fol8 resistant to benomyl $(30 \mu \mathrm{g} / \mathrm{ml})$. The fungi were kept at $3^{\circ} \mathrm{C}$ on malt agar (18) and were grown in $2 \%$ malt broth at $24^{\circ} \mathrm{C}$ with shaking (140 rpm). The conidia were collected from 3-day-old cultures by filtration and were rinsed with sterile double-distilled water. More than $90 \%$ were microconidia.
Tomato cv. Bonny Best is sensitive to pathogenic strains Fol8 and Fol8B. All seeds were surface-disinfected in $1 \%$ hydrochloric acid for $30 \mathrm{~min}$ and rinsed repeatedly in sterile double-distilled water prior to sowing. In the cutting system described below, tomato plants were sown in rockwool (type AO 36/40-10/10, Grodan, Hedehusene, Denmark). The rockwool was soaked in sterile Knop nutrient solution (modified as in Keel et al. [18]) throughout the experiment. In the other systems, sowing was carried out in autoclaved Potgrond BF4 4C potting mix (M. de Baat B.V., Coevorden, the Netherlands). All experiments were performed with 18-day-old seedlings (for the cutting system, 21-day-old seedlings were used) in a greenhouse at $50 \%$ relative humidity with $16 \mathrm{~h}$ of light $\left(25^{\circ} \mathrm{C}\right)$ and $8 \mathrm{~h}$ of dark $\left(20^{\circ} \mathrm{C}\right)$.

Bioassays for induced resistance. Four bioassays were developed to demonstrate the induction of resistance to Fusarium wilt of tomato (Fig. 1). In the split-root and layering systems, nonpathogenic strain Fo47 was separated spatially from pathogenic strain Fol8, whereas Fo47 and Fol8 (or Fol8B) were separated in time in the cutting and benomyl systems. Conidia of Fol8 (or Fol8B) were added to 50\% Knop nutrient solution in the split-root and benomyl systems, to an autoclaved potting mix in the cutting system, and to autoclaved soil collected at Eschikon, Switzerland (42), in the layering system. Inoculation with strain Fo47, Fol8, or Fol8B was performed with $10^{6}$ conidia per $\mathrm{ml}$ of nutrient solution or $\mathrm{cm}^{3}$ of rockwool, potting mix, or soil, except for Fo47, which was added at $10^{7}$ conidia per $\mathrm{ml}$ of solution in the split-root system. In all four bioassays, uninoculated controls were used in which Fo47 and Fol8 were absent.

The percentage of leaf yellowing/wilting was used to evaluate disease severity. Nine classes were established by rating symptoms on a scale of 0 to 100 (31): $0=0 \%$ foliar wilting; $2.5=(0<x \leq 5 \%)$ wilting; $12.5=(5<x \leq 20 \%)$ wilting; $30=(20<x \leq$ $40 \%)$ wilting; $50=(40<x \leq 60 \%)$ wilting; $70=(60<x \leq 80 \%)$ wilting; $87.5=(80<x$ $\leq 95 \%)$ wilting; $97.5=(95<x<100 \%)$ wilting; and $100=100 \%$ wilting (dead plant).

Benomyl system (bioassay A). Maraite (27) used benomyl to inhibit the fungal inducer and a subsequent pathogen resistant to benomyl when studying induced resistance of melon to Fusarium wilt. In the current work, 18-day-old tomato seedlings were dug from potting mix, and the roots 
were carefully washed under running tap water. The root systems of the plants were placed for 7 days in 50\% Knop nutrient solution that was either sterile or inoculated with strain Fo47. The roots were rinsed with double-distilled water, and the plants were transferred to 2-liter containers containing 50\% Knop nutrient solution and benomyl $(30 \mu \mathrm{g} / \mathrm{ml})$. Two days later, the roots were cut off $2 \mathrm{~cm}$ from the base of the hypocotyl and were placed in 50\% Knop nutrient solution containing strain Fol8B. Disease severity was evaluated 6 weeks later.

Split-root system (bioassay B). Split-root systems have been used successfully to investigate induced resistance $(19,24,26,27)$. The 18-day-old seedlings were cut off at the base of the stem, and the hypocotyls were split longitudinally in two parts with a sterile razor blade, to a length of approximately $3 \mathrm{~cm}$. Each part of the hypocotyls was placed in a different tube containing 33\% Knop nutrient solution for rooting. Eight days later, each part of the split hypocotyls was placed in a 100-ml Erlenmeyer flask filled with 50\% Knop nutrient solution. Strain Fo47 was added to one of the flasks. Ten days later, the pathogen Fol8 was inoculated into the other flask. Disease severity was evaluated 4 and 6 weeks later, as described above.

Cutting system (bioassay C). The 21day-old seedlings were cut off $0.5 \mathrm{~cm}$ from the rockwool, and the shoots were transplanted into plastic pots filled with autoclaved potting mix. Strain Fo47 was added to the rockwool prior to sowing, and Fol8 was inoculated into the potting mix prior to replanting. Disease severity was evaluated 6 weeks later.

Layering system (bioassay D). The soil was passed through a 8-mm screen before autoclaving, inoculated with Fo47 or Fol8 when appropriate, and mixed thoroughly. About $350 \mathrm{~cm}^{3}$ of inoculated soil was added on top of $100 \mathrm{~cm}^{3}$ of a mixture of coarse sand and gravels (particle size 1.8 to $2.2 \mathrm{~mm}$ ). The 18-day-old seedlings were transplanted into uninoculated soil or soil previously inoculated with Fo47 and were grown for 2 weeks. The stem of each plant was slightly grazed with a razor blade and bent until it was in contact with the soil in a second pot. In the latter pot, the stem was maintained in this position with a hook and was covered with about $1 \mathrm{~cm}$ of soil. Strain Fol8 was added to the soil of the second pot 3 days before layering. Disease severity was evaluated 8 weeks later.

Extraction of tomato tissues for study of enzymatic activity. The effect of Fo47 inoculation (in autoclaved soil or rockwool) on levels of certain plant glycosidases in stems and leaves was evaluated, using uninoculated tomato plants as the control. Eighteen-day-old plants were transplanted into autoclaved soil that was either uninoculated or inoculated with Fo47 and grown for 3 weeks before stem samples were extracted. Leaf samples were obtained from tomatoes grown for 3 weeks in autoclaved rockwool that was either uninoculated (control) or inoculated with Fo47.

Stem and leaf extracts were prepared by homogenizing frozen plant material $\left(-80^{\circ} \mathrm{C}\right)$ in $0.05 \mathrm{M}$ phosphate buffer $\left(\mathrm{KH}_{2} \mathrm{PO}_{4}\right.$ and $\mathrm{Na}_{2} \mathrm{HPO}_{4}, \mathrm{pH} 7$ ) in a 1:4 wt/vol ratio with an Ultra Turrax TP18/19 homogenizer (IKKA, Staufen, Germany) (1 min at 20,000 rpm). The slurry was filtered through four layers of cheesecloth, and the filtrate was centrifuged for $20 \mathrm{~min}$ at $10,000 \times g$ and $3^{\circ} \mathrm{C}(40)$. Except for the samples used for chitinase determination, the supernatant was dialyzed in double-distilled water for $18 \mathrm{~h}$ at $4{ }^{\circ} \mathrm{C}$.

Intercellular fluids from intact fresh leaves (second and third leaves) were collected by vacuum infiltration (35) in a phosphate (32 $\mathrm{mM})$ citrate $(84 \mathrm{mM})$ buffer, $\mathrm{pH} \mathrm{2.8,} \mathrm{con-}$ taining $1 \%$ mercaptoethanol $(25 \mathrm{ml}$ per $\mathrm{g}$ of leaf) for $20 \mathrm{~min}$. Excess fluid was re-

\section{Bioassay A: benomyl system}

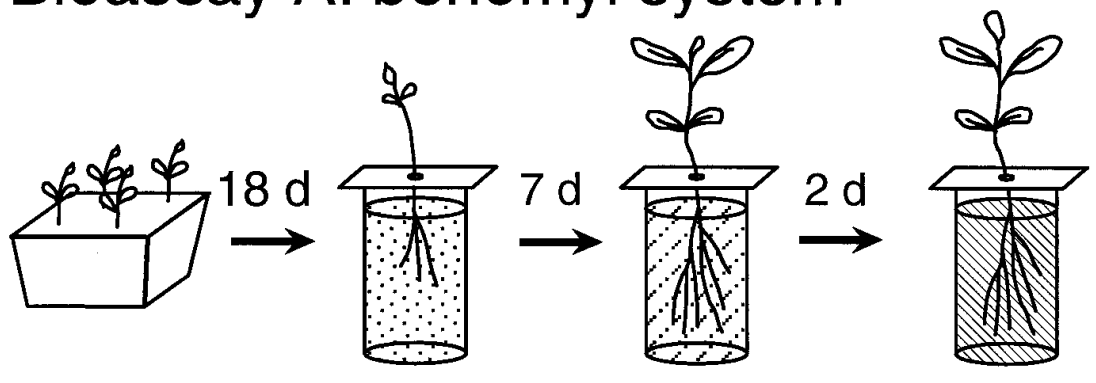

\section{Bioassay B: split root system}

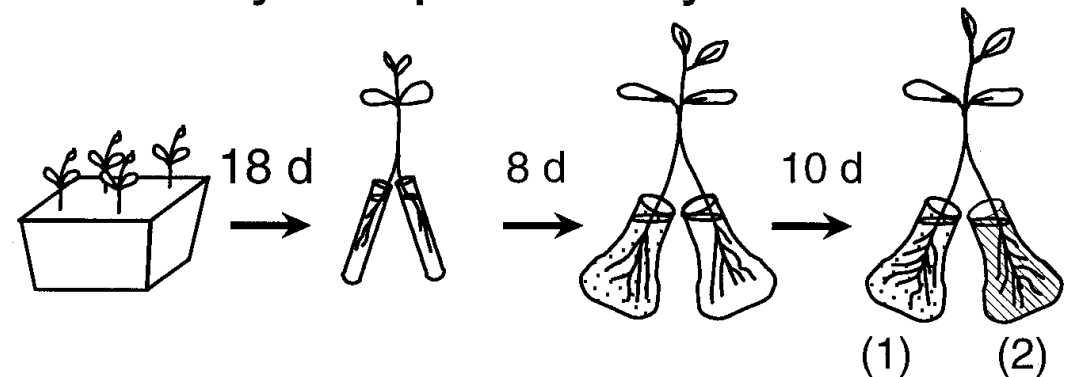

\section{Bioassay C: cutting system}

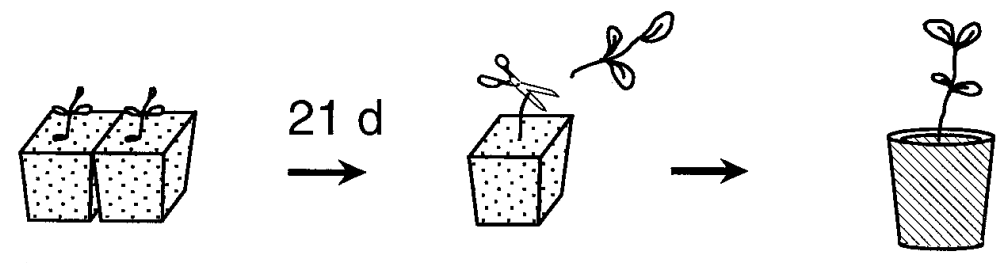

\section{Bioassay D: layering system}
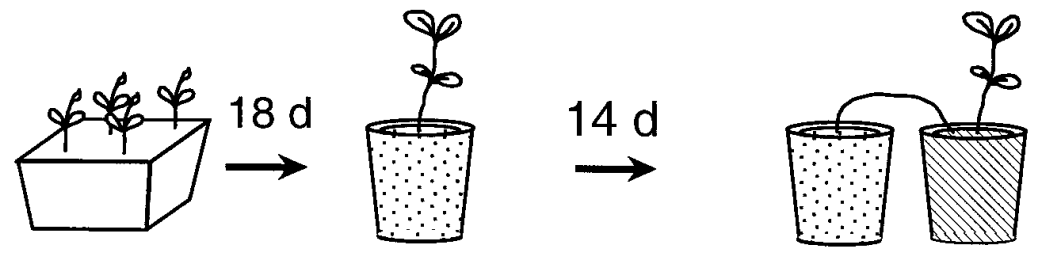

Fig. 1. Description of the four bioassays used to demonstrate the induction of resistance to Fusarium wilt in tomato plants by nonpathogenic Fusarium oxysporum strain Fo47. The pathogen used was $F$. oxysporum f. sp. lycopersici Fol8 (Fol8B in the benomyl system). Details described in text. Light dot patterns indicate inoculation with Fo47; solid, downward diagonal patterns indicate inoculation with Fol8; and broken, upward diagonal patterns indicate benomyl solution. 
moved with a paper tissue, and the intercellular fluids were recovered by centrifuging the leaves at $1,000 \times g$ and $5^{\circ} \mathrm{C}$ for 10 min. All samples were kept at $-40^{\circ} \mathrm{C}$ until assayed for enzyme activity.

Enzymatic assays. Activity of $\beta-1,4-$ glucosidase (EC 3.2.1.21; i.e., $\beta$-D-glucoside-glucohydrolase) was determined colorimetrically with $p$-nitrophenyl- $\beta$-D-glucopyranoside (Sigma Chemical Co., St. Louis) as substrate. The reaction product (i.e., $p$-nitrophenol) was determined as described by Pegg and Young (36). Units of activity were defined as the amount of enzyme releasing $100 \mu \mathrm{g}$ of $p$-nitrophenol per $\mathrm{ml}$ of reaction mixture $(100 \mu \mathrm{l}$ of plant extract and $400 \mu \mathrm{l}$ of $0.1 \mathrm{M}$ sodium acetate buffer, pH 5.2, containing $0.5 \%$ p-nitrophenyl- $\beta$-D-glucopyranoside) during $1 \mathrm{~h}$ at $34^{\circ} \mathrm{C}$.

Enzymatic activity of $\beta$-1,3-glucanase (EC 3.2.1.6; i.e., $\beta$-1,3-glucan-hydrolase or laminarinase) and chitinase (EC 3.2.1.14; i.e., chitin-glucan-hydrolase) in tomato plants was measured as described previously (30). Briefly, $\beta$-1,3-glucanase activity was determined with laminarin as a substrate and quantification of the reduced sugars colorimetrically (36). Chitinase activity in 50-ml samples of plant extract or intercellular fluid was determined in the radiochemical assay used by Boller et al. (7), in which $\left[{ }^{3} \mathrm{H}\right]$ chitin is used as substrate.

Statistical analyses. Each experiment (induced resistance bioassays and enzyme studies) was performed on several independent occasions. The variances between these repeated experiments were homogeneous; therefore, data were pooled and the repeated experiments were considered as replications (26). Means and standard deviations were calculated from the means obtained in each experiment.

Table 1. Effect of nonpathogenic Fusarium oxysporum Fo47 on Fusarium wilt of tomato caused by F. oxysporum f. sp. lycopersici Fol8 (or Fol8B) in the benomyl (bioassay A), split-root (bioassay B), cutting (bioassay C), and layering systems (bioassay D)

\begin{tabular}{|c|c|c|c|c|c|}
\hline \multicolumn{2}{|c|}{ Fungal inoculation ${ }^{y}$} & \multicolumn{4}{|c|}{ Disease index $(0-100 \% \text { scale })^{\mathrm{z}}$} \\
\hline First & $\overline{\text { Challenge }}$ & Benomyl & Split root & Cutting & Layering \\
\hline \multirow[t]{2}{*}{ None } & None & $0( \pm 0)$ & $0( \pm 0)$ & $0( \pm 0)$ & $0( \pm 0)$ \\
\hline & & $\mathrm{a}(\mathrm{a})$ & $a(a)$ & a (a) & a (a) \\
\hline \multirow[t]{2}{*}{ None } & Fol8 & $86( \pm 6)$ & $54( \pm 6)$ & $38( \pm 13)$ & $46( \pm 14)$ \\
\hline & & $\mathrm{b}(\mathrm{b})$ & $\mathrm{b}(\mathrm{b})$ & $\mathrm{b}(\mathrm{b})$ & $\mathrm{b}(\mathrm{b})$ \\
\hline \multirow[t]{2}{*}{ Fo47 } & Fol8 & $23( \pm 24)$ & $37( \pm 11)$ & $20( \pm 8)$ & $20( \pm 16)$ \\
\hline & & $\mathrm{c}(\mathrm{a})$ & $\mathrm{c}(\mathrm{c})$ & $\mathrm{c}(\mathrm{b})$ & $\mathrm{c}(\mathrm{a})$ \\
\hline
\end{tabular}

y In the benomyl system, the root systems of tomato seedlings were placed in nutrient solution containing nonpathogenic $F$. oxysporum strain Fo47 before being exposed to benomyl $(30 \mu \mathrm{g} / \mathrm{ml})$. The roots were cut off and placed in nutrient solution containing F. oxysporum f. sp. lycopersici Fol8B. In the split-root system, Fo47 was added to a flask containing one part of the split tomato hypocotyl, and F. oxysporum f. sp. lycopersici Fol8 was added to a flask containing the other part. In the cutting system, tomatoes were grown in rockwool previously inoculated with Fo47, and the shoots were transplanted into autoclaved potting mix inoculated with Fol8. In the layering system, tomato seedlings were transplanted into autoclaved soil containing Fo47, and Fol8 was added in the soil of the second pot.

${ }^{\mathrm{z}}$ Values (means \pm standard deviations) were calculated from the means obtained in each of three independent experiments, the latter being considered replications. Analyses of variance and Fisher's least significant difference tests were performed after expressing data as the percentage of the values in the treatment in which only Fol8 was added (to account for differences in disease pressure between experiments). The statistical relationships between treatments within a column $(P=0.05)$ are indicated with the letters $\mathrm{a}, \mathrm{b}$ and $\mathrm{c}$. The letters $\mathrm{a}, \mathrm{b}$, and $\mathrm{c}$ in parentheses indicate the results of analyses when means from the experiments were used without prior transformation. the roots of tomato plants after the fungicide treatment. The benomyl treatment itself had no effect on Fol8B-mediated Fusarium wilt in the absence of Fo47 (data not shown). Tomato plants never exposed to Fol8B did not develop Fusarium wilt symptoms.

In the split-root system, Fo47 and Fol8 were physically separated throughout the experiment (Fig. 1). Again, Fusarium wilt was not observed in the absence of Fol8. Inoculation of certain roots (in flask 1) with Fo47 10 days prior to inoculation of other roots (in flask 2) with Fol8 reduced the extent of Fusarium wilt from 54 to $37 \%$ at 4 weeks after challenge-inoculation with the pathogen (Table 1). Fo47 was not found in flask 2 or at stem level. However, this protective effect disappeared 2 weeks later (data not shown).

In the cutting system (Fig. 1), the presence of Fo47 in the rockwool used to grow tomato plants prior to transplantation to Fol8-inoculated potting mix (under gnotobiotic conditions) reduced Fusarium wilt from 38 to $20 \%$ (Table 1). However, fluctuation in disease pressure between experiments (standard deviation of 13\%) in this system was such that the effect of Fo47 was significant at only $P=0.059$ when statistics were performed without first expressing results as a percentage of the values in the treatment in which only the pathogen was present.

The presence of Fo47 in the first pot of the layering system (Fig. 1), in which Fol8 was added to a separate pot, resulted in a significant decrease in the extent of Fusarium wilt (Table 1). As for the benomyl and split-root systems, the protective effect of Fo47 was significant at $P=0.05$. In all four bioassays, plants were sampled to confirm the absence of Fo47 from the stems. In conclusion, separate inoculations of tomato with strains Fo47 and Fol8 (or Fol8B) reduced the severity of Fusarium wilt in all four induced resistance bioassays.

Enzymatic activity in tomato. Induced resistance typically is associated with changes in the activity of certain plant enzymes. In the current work, tomato plants grown in autoclaved soil inoculated with Fo47 showed enhanced activity of $\beta$-1,4-glycosidase $(+68 \%), \beta-1,3$-glucanase $(+220 \%)$, and chitinase $(+26 \%)$ in stems compared to an inoculated control (Table 2). Enhanced chitinase activity in the Fo47 treatment was observed also in leaf extracts $(+37 \%)$ and leaf intercellular fluid $(+55 \%)$ of tomato plants grown in rockwool (Table 2).

\section{DISCUSSION}

Induced resistance is a general response of plants to certain nonpathogenic strains of bacteria, fungi, and viruses $(6,9,20,28$, 39) or host-incompatible nematodes (34). For instance, Ishiba et al. (16) found that prior inoculation of the hypocotyl with a nonpathogenic strain of $F$. oxysporum $\mathrm{f}$. sp. cucumerinum protected cucumber leaves 
from the fungal pathogen Colletotrichum lagenarium. Likewise, inoculation of roots of cucumber with $F$. oxysporum f. sp. melonis resulted in the protection of a distant root from $F$. oxysporum f. sp. cucumerinum (12). Often, the strain mediating induced resistance is closely related to the pathogen against which the plant has become protected $(6,10,12,28,39)$. Furthermore, the most effective inducers of resistance to pathogenic fungi are often found among strains belonging to the same fungal species or forma specialis $(6,10)$.

The current work was carried out with $F$. oxysporum Fo47, a nonpathogenic strain with promising biocontrol ability under both laboratory and commercial greenhouse conditions (1). Indeed, a single inoculation of cv. Bonny Best tomato plants with strain Fo47 never resulted in disease symptoms, and the presence of F. oxysporum f. sp. lycopersici Fol8 was necessary to cause Fusarium wilt. In previous investigations, evidence of induced resistance was sometimes obtained by experimental set-ups in which direct interactions between the inducer and the pathogenic strain could not be ruled out $(6,10,11,25,40)$, as noted in recent reports $(1,19,28)$. Therefore, four bioassays were developed (Fig. 1) in which nonpathogenic strain Fo47 and pathogenic strain Fol8 were introduced separately in space (split-root and layering systems) or time (benomyl and cutting systems). In these bioassays, a single inoculation with Fol8 (or Fol8B) resulted in incidence of Fusarium wilt between 38 and $86 \%$.

Fo47 protected tomato from Fol8-mediated Fusarium wilt in all four bioassays. Interestingly, Fo47 was a less effective biocontrol agent in the split-root system than in the three other systems. The inoculum level for Fo47 used in the other bioassays was insufficient to protect tomatoes against Fol8 in the split-root system, and Fo47 had to be applied at $10^{7}$ instead of $10^{6}$ conidia per $\mathrm{ml}$ of nutrient solution to achieve successful induced resistance. Protection was short-lived and had disappeared at 6 weeks after challenge-inoculation with Fol8 (data not shown). In contrast, a lower inoculum level of Fo47 (i.e., $10^{6}$ conidia of Fo47 per $\mathrm{ml}$ of substrate) resulted in efficient protection of tomatoes against Fusarium wilt throughout the experiments in the other bioassays. Overall, the addition of Fo47 reduced Fusarium wilt by 17 (split-root system) to $63 \%$ (benomyl system) of the disease index.

In the current work, nonpathogenic strain Fo47 protected tomato plants from Fusarium wilt, despite not being in direct contact with the pathogen. This indicates that protection did not result from antagonism or competition between Fo47 and Fol8 and suggests that strain Fo47 induced resistance to Fusarium wilt in tomato. This hypothesis is supported by the observation that a single inoculation with Fo47 resulted in physiological changes in the stems and leaves of tomato plants that are commonly associated with systemic induced resistance (20), including enhanced activity of chitinase $(13,15,29,32,33,40,41), \beta$-1,3-glucanase $(17,29,40,41)$, and $\beta-1,4$-glucosidase $(36$, 40). Although it is possible that Fo47 could have produced a substance transported within the plant that stimulated defense mechanisms in particular plant tissues or cells (i.e., local induced resistance), results obtained here point collectively to the induction of systemic resistance (i.e., involving the formation and transduction of a signal in the root and leading to protection of the whole tomato plant). Further work, however, is needed to confirm this hypothesis.

The current work demonstrates that induced resistance of tomato to Fusarium wilt can be implemented by a nonpathogenic strain of $F$. oxysporum. Kroon et al. (19) induced resistance to Fusarium wilt in tomato with a strain of $F$. oxysporum pathogenic on carnation, and Mandeel and Baker (26) induced resistance to Fusarium wilt in cucumber with a nonpathogenic strain of $F$. oxysporum. However, these reports did not mention whether protection involved physiological modifications in the plant. The physiological changes observed here with strain Fo47 are in accordance with the results of Tamietti et al. (40), who observed enhanced enzymatic activity in the cellular fluids of stems, leaves, and roots of tomato plants grown in a suppressive soil (or in the same soil once steamed and inoculated with nonpathogenic strains of $F$. oxysporum) compared to those in tomato plants grown in a conducive soil.

From a crop protection point of view, nonpathogenic strains of $F$. oxysporum represent a key component of the soil microbiota in soils suppressive to Fusarium wilt $(1,28,38,40)$. Interestingly, several mechanisms other than induced resistance have been proposed to explain the biocontrol ability of strain Fo47, i.e., competition for sites on the root surface (2), for iron (22), or for carbon sources (3). Indeed, fusaria compete with each other in soil before reaching the infection court (1) and for infection sites at the root surface (37). For instance, Alabouvette et al. (3) showed that a suppressive soil can become conducive to $\mathrm{Fu}$ sarium wilt after a glucose amendment. However, the latter can also inhibit induced resistance (12). Overall, the protection of tomato plants by Fo47 probably results from a combination of these different biocontrol mechanisms. In the current work, omitting the benomyl treatment in the first bioassay did not lead to better protection of tomato by Fo47, suggesting that induced resistance was the only biocontrol mechanism involved. However, protection of tomatoes against Fusarium wilt in the splitroot system was better when both Fo47 and Fol8 were introduced in the same flask (i.e., in flask 2; disease index of only $12 \%$ ), indicating that direct interactions between the two strains also could lead to reduced disease severity. Likewise, protection of cucumber against Fusarium wilt by a nonpathogenic strain of $F$. oxysporum involved both competition for infection sites and induced resistance (26).

Better knowledge of the mechanisms involved in the protection of plants by biocontrol agents is a prerequisite to the development of successful biocontrol strategies for use under commercial conditions. The ability of Fo47 to induce resistance to Fusarium wilt in tomato plants has important commercial implications, because it necessitates the exposure of tomato plants to Fo47 at an early stage for efficient induced resistance against subsequent attack by Fusarium wilt fungi. The amount of time needed for induced resistance is determined both by the host-pathogen system and the experimental set-up; one to a few days are

Table 2. Effect of nonpathogenic Fusarium oxysporum Fo47 on enzymatic activity in stems and leaves of tomato plantsw

\begin{tabular}{lccccc}
\hline & & & \multicolumn{3}{c}{ Chitinase } \\
\cline { 5 - 6 } Inoculation & $\begin{array}{c}\beta-1,4- \\
\text { glucosidase }^{\mathrm{x}}\end{array}$ & $\begin{array}{c}\beta-1,3- \\
\text { glucanase }^{\mathrm{x}}\end{array}$ & $\begin{array}{c}\text { Stem } \\
\text { extract }^{\mathrm{x}}\end{array}$ & $\begin{array}{c}\text { Leaf } \\
\text { extract }^{\mathrm{y}}\end{array}$ & $\begin{array}{c}\text { Leaf intercellular } \\
\text { fluid }^{\mathbf{y}}\end{array}$ \\
\hline None & $100 \mathrm{a}^{\mathrm{z}}$ & $100 \mathrm{a}$ & $100 \mathrm{a}$ & $100 \mathrm{a}$ & $100 \mathrm{a}$ \\
Fo47 & $168 \mathrm{~b}$ & $315 \mathrm{~b}$ & $126 \mathrm{~b}$ & $137 \mathrm{~b}$ & $155 \mathrm{~b}$ \\
\hline
\end{tabular}

${ }^{w}$ Eighteen-day-old tomato plants (cv. Bonny Best) were transplanted into autoclaved soil or rockwool previously inoculated with $F$. oxysporum Fo47 $\left(10^{6}\right.$ conidia per $\left.\mathrm{cm}^{3}\right)$. Samples for enzymatic activity determinations were collected 3 weeks later.

${ }^{x}$ Stem extracts were obtained from tomato plants grown in autoclaved soil. Enzymatic activities in stem extracts are given as the percentages of those for the uninoculated control, i.e., $\beta$-1,4-glucosidase, 30.3 units per $g$ of stem; $\beta$-1,3-glucanase, 3.49 units per $g$ of stem; and chitinase, 137 pkat per $\mathrm{g}$ of stem.

${ }^{y}$ Leaf extracts and leaf intercellular fluids were obtained from tomatoes grown in autoclaved rockwool. Chitinase activities for leaf samples are given as the percentages of those for the uninoculated control, i.e., 667 pkat per $\mathrm{g}$ of leaf (for leaf extracts) and 30 pkat per $\mathrm{ml}$ of fluid (for leaf intercellular fluids)

${ }^{z}$ Values were obtained by averaging means from three (indicated by footnote mark $\mathrm{x}$ ) or four (indicated by footnote mark y) independent experiments. In each experiment, activities were determined for three (indicated by footnote mark $\mathrm{x}$ ) or two (indicated by footnote mark y) samples. Each experiment was considered one replication in the statistical analyses. Each enzymatic activity was statistically different in the Fo47 treatment and the uninoculated control, as indicated by letters a and $\mathrm{b}$ within a column $(P=0.05$, analysis of variance $)$. 
needed for Fusarium wilts (28). Timing is also important because induced resistance provides protection that is of limited duration in certain cases (28). On the other hand, induced resistance is rather nonspecific (20), which may allow Fo47 to protect tomato plants against other pathogens as well, e.g., the fungi Phytophthora infestans and Cladosporium fulvum. Further work will assess whether Fo47-mediated induced resistance of tomato to Fusarium wilt can lead to protection of the plant against other pathogens.

\section{ACKNOWLEDGMENTS}

This work was supported by the Bundesamt für Landwirtschaft of Switzerland. We thank C. Gessler from our institute for suggestions regarding the benomyl system and C. Alabouvette and P. Lemanceau (INRA, Dijon, France) for providing strains Fo47 and Fol8 and for helpful discussions.

\section{LITERATURE CITED}

1. Alabouvette, C., and Couteaudier, Y. 1992. Biological control of Fusarium wilts with nonpathogenic fusaria. Pages 415-426 in: Biological Control of Plant Diseases: Progress and Challenges for the Future. E. C. Tjamos, G. C. Papavizas, and R. J. Cook, eds. Plenum Press, New York.

2. Alabouvette, C., Couteaudier, Y., and Louvet, J. 1984. Recherches sur la résistance des sols aux maladies. X. Comparaison de la mycoflore colonisant les racines de melons cultivés dans un sol résistant ou dans un sol sensible aux fusarioses vasculaires. Agronomie 4:735740 .

3. Alabouvette, C., Couteaudier, Y., and Louvet, J. 1985. Recherches sur la résistance des sols aux maladies. XI. Etude comparative du comportement des Fusarium spp. dans un sol résistant et un sol sensible aux fusarioses vasculaires enrichis en glucose. Agronomie 5:63-68.

4. Alabouvette, C., de la Broise, D., Lemanceau, P., Couteaudier, Y., and Louvet, J. 1987. Utilisation de souches non pathogènes de Fusarium pour lutter contre les fusarioses: Situation actuelle dans la pratique. EPPO Bull. 17:665674.

5. Benhamou, N., Charest, P. M., and Jarvis, W. R. 1989. Biology and host-parasite relationships of Fusarium oxysporum. Pages 95-105 in: Vascular Wilt Diseases of Plants. Basic Studies and Control. E. C. Tjamos and C. H. Beckman, eds. NATO ASI Series, vol. H28. Springer-Verlag, Berlin.

6. Biles, C. L., and Martyn, R. D. 1989. Local and systemic resistance induced in watermelons by formae speciales of Fusarium oxysporum. Phytopathology 79:856-860.

7. Boller, T., Gehri, A., Mauch, F., and Vögeli, U. 1988. Chitinase from Phaseolus vulgaris leaves. Methods Enzymol. 161:479-484.

8. Couteaudier, Y. 1989. Interactions microbiennes dans le sol et la rhizosphère: Analyse du déterminisme de la compétition entre populations de Fusarium. Ph.D. dissertation. Université Lyon I, Lyon, France.

9. Cramer, C. L., Ryder, T. B., Bell, J. N., and Lamb, C. J. 1985. Rapid switching of plant gene expression induced by fungal elicitors. Science 227:1240-1243.

10. Davis, D. 1967. Cross-protection in Fusarium wilt diseases. Phytopathology 57:311-314.

11. Davis, D. 1968. Partial control of Fusarium wilt in tomato by formae of Fusarium oxysporum. Phytopathology 58:121-122.

12. Gessler, C., and Kuć, J. 1982. Induction of resistance to Fusarium wilt in cucumber by root and foliar pathogens. Phytopathology 72: 1439-1441.

13. Grenier, J., and Asselin, A. 1990. Some pathogenesis-related proteins are chitosanases with lytic activity against fungal spores. Mol. PlantMicrobe Interact. 3:401-407.

14. Hervás, A., Trapero-Casas, J. L., and JiménezDíaz, R. M. 1995. Induced resistance against Fusarium wilt of chickpea by nonpathogenic races of Fusarium oxysporum f. sp. ciceris and nonpathogenic isolates of $F$. oxysporum. Plant Dis. 79:1110-1116.

15. Irving, H. R., and Kuć, J. 1990. Local and systemic induction of peroxidase, chitinase and resistance in cucumber plants by $\mathrm{K}_{2} \mathrm{HPO}_{4}$. Physiol. Mol. Plant Pathol. 37:355-366.

16. Ishiba, C., Tani, T., and Murata, M. 1981. Protection of cucumber against anthracnose by a hypovirulent strain of Fusarium oxysporum f. sp. cucumerinum. Ann. Phytopathol. Soc. Jpn. 47:352-359.

17. Ji, C., and Kuć, J. 1995. Purification and characterization of an acidic $\beta$-1,3-glucanase from cucumber and its relationship to systemic disease resistance induced by Colletotrichum lagenarium and tobacco necrosis virus. Mol. Plant-Microbe Interact. 8:899-905.

18. Keel, C., Voisard, C., Berling, C. H., Kahr, G., and Défago, G. 1989. Iron sufficiency, a prerequisite for suppression of tobacco black root rot by Pseudomonas fluorescens strain CHA0 under gnotobiotic conditions. Phytopathology 79:584-589.

19. Kroon, B. A. M., Scheffer, R. J., and Elgersma, D. M. 1991. Induced resistance in tomato plants against Fusarium wilt invoked by Fusarium oxysporum f. sp. dianthi. Neth. J. Plant Pathol. 97:401-408.

20. Kuć, J. 1982. Induced immunity to plant disease. BioScience 32:854-860.

21. Lemanceau P., and Alabouvette, C. 1991. Biological control of Fusarium diseases by fluorescent Pseudomonas and non-pathogenic $\mathrm{Fu}$ sarium. Crop Prot. 10:279-286.

22. Lemanceau, P., Alabouvette, C., and Couteaudier, Y. 1988. Recherches sur la résistance des sols aux maladies. XIV. Modification du niveau de réceptivité d'un sol résistant et d'un sol sensible aux fusarioses vasculaires en réponse à des apports de fer et de glucose. Agronomie 8:155-162.

23. Lemanceau, P., Bakker, P. A. H. M., de Kogel, W. J., Alabouvette, C., and Schippers, B. 1992. Effect of pseudobactin 358 production by Pseudomonas putida WCS358 on suppression of Fusarium wilt of carnations by nonpathogenic Fusarium oxysporum Fo47. Appl. Environ. Microbiol. 58:2978-2982.

24. Liu, L., Kloepper, J. W., and Tuzun, S. 1995. Induction of systemic resistance in cucumber against Fusarium wilt by plant growth-promoting rhizobacteria. Phytopathology 85:695698.

25. Louter, J. H., and Edgington, L. V. 1990. Indications of cross-protection against Fusarium crown and root rot of tomato. Can. J. Plant Pathol. 12:283-288.

26. Mandeel, Q., and Baker, R. 1991. Mechanisms involved in biological control of Fusarium wilt of cucumber with strains of nonpathogenic Fusarium oxysporum. Phytopathology 81:462-469.

27. Maraite, H. 1982. Induced resistance in muskmelon wilt: Facts and limitations. Pages 339340 in: Active Defense Mechanism in Plants. R. K. S. Wood, ed. Plenum Press, New York.
28. Matta, A. 1989. Induced resistance to Fusarium wilt diseases. Pages 175-196 in: Vascular Wilt Diseases of Plants. Basic Studies and Control. E. C. Tjamos and C. H. Beckman, eds. NATO ASI Series, vol. H28. SpringerVerlag, Berlin.

29. Matta, A., Gentile, I. A., and Ferraris, L. 1988. Stimulation of $\beta$-1,3-glucanase and chitinase by stresses that induce resistance to Fusarium wilt in tomato. Phytopathol. Mediterr. 27:4550

30. Maurhofer, M., Hase, C., Meuwly, P., Métraux J.-P., and Défago, G. 1994. Induction of systemic resistance of tobacco to tobacco necrosis virus by the root-colonizing Pseudomonas fluorescens strain CHA0: Influence of the gacA gene and of pyoverdine production. Phytopathology 84:139-146.

31. Maurhofer, M., Keel, C., Haas, D., and Défago, G. 1995. Influence of plant species on disease suppression by Pseudomonas fluorescens strain CHA0 with enhanced antibiotic production. Plant Pathol. 44:40-50.

32. Métraux, J.-P., and Boller, T. 1986. Local and systemic induction of chitinase in cucumber plants in response to viral, bacterial, and fungal infections. Physiol. Mol. Plant Pathol. 28: 161-169.

33. Métraux, J.-P., Streit, L., and Staub, T. 1988. A pathogenesis-related protein in cucumber is a chitinase. Physiol. Mol. Plant Pathol. 33:1-9.

34. Ogallo, J. L., and McClure, M. A. 1995. Induced resistance to Meloidogyne hapla by other Meloidogyne species on tomato and pyrethrum plants. J. Nematol. 27:441-447.

35. Parent, J.-G., and Asselin, A. 1984. Detection of pathogenesis-related proteins (PR or b) and of other proteins in the intercellular fluid of hypersensitive plants infected with tobacco mosaic virus. Can. J. Bot. 62:564-569.

36. Pegg, G. F., and Young, D. H. 1981. Changes in glycosidase activity and their relationship to fungal colonization during infection of tomato by Verticillium albo-atrum. Physiol. Plant Pathol. 19:371-382.

37. Schneider, R. W. 1984. Effects of nonpathogenic strains of Fusarium oxysporum on celery root infection by $F$. oxysporum $\mathrm{f}$. sp. apii and a novel use of the Lineweaver-Burk double reciprocal plot technique. Phytopathology 74:646-653.

38. Smith, S. N., and Snyder, W. C. 1971. Relationship of inoculum density and soil types to severity of Fusarium wilt of sweet potato. Phytopathology 61:1049-1051.

39. Strömberg, A. 1989. Systemically Induced Resistance in Tomatoes, Tobacco and Potatoes: A Literature Review. Växtskyddsrapporter, Jordbruk 55. Research Information Centre, Swedish University of Agricultural Sciences, Uppsala.

40. Tamietti, G., Ferraris, L., Matta, A., and Abbattista Gentile, I. 1993. Physiological responses of tomato plants grown in Fusarium suppressive soil. J. Phytopathol. 138:66-76.

41. Tuzun, S., Nageswara Rao, M., Vogeli, U., Schardl, C. L., and Kuć, J. 1989. Induced systemic resistance to blue mold: Early induction and accumulation of $\beta$-1,3-glucanases, chitinases, and other pathogenesis-related proteins (b-proteins) in immunized tobacco. Phytopathology 79:979-983.

42. Wüthrich, B., and Défago, G. 1991. Suppression of wheat take-all and black root rot of tobacco by Pseudomonas fluorescens strain CHA0: Results of field and pot experiments. Pages 17-22 in: Plant Growth-Promoting Rhizobacteria: Progress and Prospects. C. Keel, B. Koller, and G. Défago, eds. IOBC/WPRS Bull. XIV/8, Interlaken, Switzerland. 